\title{
Food sovereignty and sustainability mid-pandemic: how Michigan's experience of Covid-19 highlights chasms in the food system
}

\author{
Sarah King ${ }^{1}\left[\right.$. Amy McFarland ${ }^{1} \cdot$ Jody Vogelzang ${ }^{1}$ \\ Accepted: 16 September 2021 / Published online: 25 September 2021 \\ (c) The Author(s), under exclusive licence to Springer Nature B.V. 2021
}

\begin{abstract}
This paper offers observations on people's lived experience of the food system in Michigan during the early Covid-19 pandemic as an initial critical foray into the everyday pandemic food world. The Covid-19 crisis illuminates a myriad of adaptive food behaviors, as people struggle to address their destabilized lives, including the casual acknowledgement of the pandemic, then anxiety of the unknown, the subsequent new dependency, and the possible emergence of a new normal. The pandemic makes the injustices inherent in the food system apparent across communities, demonstrating that food injustice destabilizes all members of the food system, regardless of their social location. The challenges of eating in a pandemic also reinforce the importance of building a sustainable food system; the challenges of food sovereignty and food sustainability are inextricably linked, and the pandemic lays this bare.
\end{abstract}

Keywords Covid-19 $\cdot$ Pandemic $\cdot$ Food systems $\cdot$ Sustainability $\cdot$ Food sovereignty $\cdot$ Food behaviors $\cdot$ Michigan $\cdot$ Hoarding $\cdot$ Anxiety $\cdot$ New dependency $\cdot$ Food justice

\section{Introduction}

On March 10, 2020, Michigan Governor Gretchen Whitmer announced that the first two presumptive positive cases of Covid-19 had arrived in Michigan and declared a state of emergency. On March 11 universities across the state closed, and on March 12 the closure of all K-12 schools was announced (the initial 3-week closure was later extended to cover the remaining school year). The "Stay Home, Stay Safe" order requiring all Michigan residents to stay-at-home unless meeting essential needs, was issued on March 24, extended on April 9 and then again to May 15. Many social structures dramatically changed or shut down, hoarding and scarcity entered the common parlance, grocery store workers became "front line personnel," and home gardens skyrocketed in popularity. As scholars committed to the development of a just, healthy, place-based food system, we were participant observers in the unprecedented set of social shifts captured here. This paper was developed and written from

Sarah King

dr.sarah.king@gmail.com

1 Grand Valley State University, Grand Rapids \& Allendale, MI, USA
mid-March to May 2020, while the stay-at-home order was in place, and the pandemic experience ongoing.

In the season of a global pandemic, many people face the challenge of how to get food; healthy food, food they like to eat, any food. Examining the challenges of everyday life is central to understanding social structures as Lefebvre argued and as the work of David Harvey $(2005,2012)$ demonstrates. This is particularly true in the areas of everyday life that are gendered, as the feminist sociologist Dorothy Smith points out. Smith argued that in order to develop concepts that "explicate actual social relations" scholars must take "the everyday world as [our] problematic" (1987). In pandemic, the everyday world is problematic even for many who are typically unaware of the failures of the global industrial food system. This essay offers preliminary reflections based on observations made by the authors and triangulated with state-wide news articles and conversations. The authors took on a reflexive role, validated their observations across many food-related organizations, generating a critical analysis of pandemic-induced food behaviors during the early stages of the pandemic.

The Covid-19 crisis precipitates a variety of adaptive food behaviors, as people struggle to address their destabilized lives, including the casual acknowledgement of the pandemic, then anxiety of the unknown, the subsequent new 
dependency, and the possible emergence of a new normal, which we explore below. For the three authors, as scholars, citizens and eaters, the shifting relationships our communities have with food during this pandemic raise important questions about how food operates as a currency of power. The pandemic makes the injustices inherent in the food system apparent across communities, demonstrating that food injustice destabilizes all members of the food system, regardless of their social class or location. The challenges of eating in a pandemic also reinforce the importance of building a sustainable food system; the challenges of food sovereignty and food sustainability are inextricably linked, and the pandemic lays this bare. This paper offers early observations on people's lived experience of the food system as an initial critical foray into the everyday pandemic food world, with the certainty that there is much more to be said about the implications of these no-longer-hidden inequities and vulnerabilities for everyone who eats.

\section{Methods}

This paper develops a phenomenological analysis of the early months of pandemic in Michigan drawing on participant observation and a collected archive documenting the impact of pandemic on the Michigan food system. The three authors commenced their work as participant observers of the Michigan food system in pandemic in early March 2020, simultaneously collaborating to build an archive of materials capturing stories and data on the experiences of communities, farms and businesses across the state during the same time period (Cresswell 2012; Mathison 1988; Smith 1987). Using a phenomenological approach, findings from participant observation were triangulated with materials in the developing archive to identify key themes, experiences and issues. This iterative analysis prioritized the everyday experiences of Michiganders as phenomena which, when better understood, would lay bare structures of power that had been taken-for-granted. Analyzing observed behaviors of everyday lived experience, drawn from participant observation and archival examples, coupling reflexivity with framing (Chong and Druckman 2007; Fook 1999), led to new insights about the stages of pandemic experience on the ground in Michigan which may be relevant more broadly, particularly across North America.

\section{Pandemic induced food behaviors}

For almost 90 days the authors observed the pandemic grow and evolve in the state of Michigan. While Western and Northern Michigan watched the numbers of positive cases and deaths mount on the East side of the state, there was a flurry of activity in supermarkets across the state. In reflecting on this buying frenzy and its aftermath, five types of pandemic food behaviors are evident:

1. the casual acknowledgement of the pandemic resulting in the light stocking up observed early in the pandemic as reports of cases on the west coast of the United States began (February-March 2020);

2. food hoarding seen from anxiety of the unknown as cases started to be identified within the state of Michigan (March 2020);

3. the new dependency on food charity due to skyrocketing unemployment and school closures by people who had never accessed these resources before (March 2020-present);

4. the attempt to control food access, despite the lingering threat of the virus, by utilizing local food systems and planting gardens in record numbers while farms and farmers shift business models to serve their local communities (April 2020-present); and,

5. the emergence of an early form of new normal as life continues post stay-at-home-pandemic (still emerging).

It is possible that pandemic-induced changes in the food system may persist after the new normal begins as demonstrated by increased interest and participation in local food systems. The movement towards a just and sustainable food system for all requires continued attention, vigilance, and advocacy on the part of eaters, activists, and policymakers.

\section{Casual acknowledgement}

One of the major interventions in slowing a pandemic caused by a virus with no cure is social distancing and "stayat-home" orders. For many Michiganders, the early stages of the Covid-19 virus seemed comparable to other situations requiring staying at home and isolation that come with the territory such as snow days (and sometimes snow weeks). As weather apps on phones warn people of approaching snowstorms, they might leave work early to "stock-up," sometimes finding they are too late to get a favorite loaf of bread and having to settle for a second choice. There is a bit of excitement as people talk to fellow shoppers about the impending snowstorm and share approaches in preparing and waiting.

Common concerns involve power outages and keeping the freezer shut (not empty pantries and daily death reports). Similarly, during the early stages of the Covid-19 virus in Michigan, many consumers realized that extra food supplies might be required, and just as in a bad snowstorm, there would be some difficult and isolating days which required a stocking-up on basic items, commonly bread, milk, snacks, 
beer, and toilet paper (ready.gov 2021). This casual acknowledgment of a far-away crisis was the first stage of pandemic food behavior. This stage was more of a reflexive, learned response based on generational knowledge of how to prepare for an emergency that would require time spent inside. It was assumed that this pandemic would abide by expectations and not test people's preparation. But the experience of Covid-19 is not at all like a snowstorm.

\section{The anxiety of the unknown}

As Mid-Westerners watched the impact of this virus on the West Coast, and the resulting deaths in Washington, and then New York, something more was happening closer to home. The southeast side of Michigan was also reporting positive Covid-19 screenings and related deaths. What looked like an isolated illness happening thousands of miles away was now a very real and threatening event. Watching Covid-19 as only a mildly engaged spectator rapidly changed. The realization of possible personal endangerment introduced the second stage of food procurement-anxiety of the unknown. Supermarkets and food clubs were overrun with people purchasing vast amounts of toilet paper and food items. Enormous online companies were swamped with orders causing buying limits to be put on many food staples. Consumers all over the United States, Michigan included, engaged in bulk-buying causing empty grocery shelves and generating widespread panic (Preston 2020).

As the number of Covid-19 cases grew on the east side of Michigan, more residents moved swiftly into volume food procurement. Food hoarding has been used to explain and label the behavior of food acquisition in anticipation of illness and isolation related to the pandemic. Food hoarders were shamed in social media as being selfish however, hoarding is also a medical diagnosis indicating indiscriminate acquisition of goods and things to the point of selfendangerment (Shaeffer 2017; Akhtar 2019). Food hoarding associated with an impending crisis does not imply a psychological problem but may be fueled by past experiences of food scarcity, anxiety related to circumstances out of personal control, and the driving need to protect a family unit (Helton et al. 2017). Excessive acquisition can indicate a higher intolerance of uncertainty (Davidson et al. 2019).

In this pandemic there appeared to be a direct relationship between feeling safe and possessing an abundance of food. Hoarding in general, and food hoarding specifically, provides hope and security (Akhtar 2019). This optimism and confidence in being able to withstand the unknown provided a feeling of stability and helped mitigate the feeling of anxiety of the unknown (Arslan et al. 2021). There is also a sense of pleasure or accomplishment after successfully locating an item that is in short supply (Akhtar 2019). Social media was buzzing with tips on where to find hand sanitizer, toilet paper, eggs, rice, and flour. It was a scavenger hunt, and the prize went to the fastest and most aggressive shopper.

Acquisition of scarce and widely sought-after items promoted feelings of resourcefulness and the self-efficacy of being able to face anything that this pandemic brings. During the secondary stage of pandemic shopping, the acquisition of toilet paper was almost impossible. Media included pictures of carts piled high with rolls and rolls of toilet paper and people lining up before a store opened to stock- up. In fact, people who were able were hoarding food in equal measure. National consumer data indicates that shoppers rushed to stock their pantries with shelf-stable food during the last week of February 2020, as seen in the increased sales of dried beans $(+37 \%)$, canned meat $(+32 \%)$ and rice $(+25 \%)$ (Nielsen 2020). The procurement of large amounts of food and other supplies disrupted the food chain and caused scarcity for others who may not have had the time or money to travel to several stores and spend hundreds of dollars in a short span of time.

\section{New dependency}

As the stay-at-home period was prolonged, many previously employed workers were now without paid work. Missing paychecks led more people to experience a new dependency on the charity food system. Michigan saw massive layoffs of over one million people in a one-month period (Gardner 2020) which decimated family budgets and caused a sharp uptick in the use of food pantries. The food crisis was so desperate that the Michigan National Guard was deployed to help deliver food from the food banks (Boldrey 2020a). The first wave of those needing emergency food were those at high risk for dependency because of socio-economic factors. O'Sullivan and Phillips (2019) describe this group as having lower adaptive capacity because of fluctuating resources and subsequently less empowerment, limited options, and increased dependency.

The burden of scarcity fell disproportionately on those lacking private transportation to ferry home large quantities of household goods, those without financial reserves for a \$300-\$1000 shopping trip, and those with unsafe, or inadequate food storage space. Because of the lag in becoming eligible for social programs and overall lack of preparedness by the federal and state governments, the disruption in normal food procurement drove people to private charities to obtain necessary food and supplies for their families. According to the April 2, 2020 edition of The Guardian (Lakhani 2020), the demand for emergency food from food banks and pantries increased eightfold in just a few weeks. In Michigan, as in other states, school closures also contributed to the dependence on charity. More mouths to feed at home, less access to food programs for children, and massive unemployment were the trifecta for a new level of dependence on 
charity food. Many Michigan cities are highly racialized and segregated, and people in these communities were disproportionately affected by these challenges. A state-wide poll conducted in this period found that " $54 \%$ of furloughed/laid off residents are worried about putting food on their table; 54\% of African American residents are worried about putting food on their table, and 45\% of those aged 18-29 and $40 \%$ of those aged 30-39 are worried about putting food on their table" (Glengariff Group 2020 p. 6).

Private charities were able to pivot and meet the demand for emergency food but the existing delivery model of clients personally shopping the shelves of a pantry needed to be modified. At Streams of Hope in Grand Rapids (2020), and at many other MI locations, a "drive-through" model was developed meaning that the food was packed into boxes and dropped into car trunks. In this way the food center remained open yet practiced social distancing. Although necessary, the shift in the service model curtailed personal interaction and food choice, it addressed hunger and focused on food access, but not individual control (Wittman 2011). Households had no voice in determining what foods were being deposited in their car trunk. Would it be something the children would eat? Would they know how to cook it? Would it meet cultural preferences? For over a decade, charity food providers have worked to make their services more client centered with special attention to dignity, empowerment, and autonomy (Booth et al. 2018). In a matter of days this pandemic, with the need for personal isolation to help control the spread, had taken any focus on food sovereignty out of food charity. However, this "deposit and drive" model did allow families to have access to food without endangering themselves or the volunteers.

When the pandemic threat closed schools and teaching shifted from brick and mortar to virtual delivery, school meals also needed to shift delivery methods and adjust menus (United States Department of Agriculture 2020). Some school districts, such as Grand Rapids Public Schools, shifted to a free "Grab and Go" bag picked up at central locations within the school district. Many school districts were able to expand the sack lunch program to include preschoolers as well as current students. In rural areas, some districts such as Roscommon County were running the usual bus routes carrying food instead of children, distributing food sacks containing enough food for breakfast and lunch for four days (House 2020). This delivery method decreased the drive for families and made food more available and convenient. These pre-made lunches were vital to families facing food insecurity; however, the necessary accommodations to a new style of service meant that schools had to draw back from the "made from scratch" lunches that have become more common over the last decade to no-choice meal kits. The lack of choice in school food service during Covid-19 negated personal autonomy; participants were given no choice in food items; instead, they were presented with a binary choice of participating in the meal sites or not. The focus of front-line school food providers was to feed the kids. Their effectiveness was described in the number of meals served, not in how the system facilitated personal food autonomy during the pandemic.

During the Covid-19 pandemic every facet of food provision including access, choice, and availability is challenged. From empty grocery shelves to emergency food boxes and sack lunches, food choice is obliterated. The right to choose foods that meet personal definitions of healthy, culturally appropriate, family friendly, and tasty was sidelined in less than $48 \mathrm{~h}$. The novel coronavirus not only robbed Michiganders of their health (and life) but also destroyed self-efficacy and magnified dependence. Bare grocery shelves, which persisted into the eighth week of the stay-at home period, caused continuous anxiety built on perceived food insecurity. It demands that food choice be based on what is left on the shelf with no nod to healthy or culturally appropriate food. Choice is stripped and individual and household food autonomy abandoned. This observation builds a strong case for a more robust local food system with the ability to pivot in unprecedented times, a system that values food autonomy, sovereignty, sustainability, diversity, and resiliency as a matter of course.

\section{Attempting control}

A fourth stage of pandemic-induced food behavior began to emerge in Michigan in late April and early May 2020. Anxiety of the unknown and new dependency started to drive more people to utilize local food systems than in recent years. For example, small butcher shops in Grand Rapids and, indeed, across the country, have reported spikes in sales (Domol 2020; Hastings 2020; Snyder 2020). These increases are not limited to meat, but are seen across the spectrum of food items, including local millers (Halloran 2020) and local fruit and vegetable producers (Bell 2020). Increased use of local food systems, purchasing Community Sustainable Agriculture shares (CSA), planting home gardens, and shifting models for local farms are evident in the adjustments that some are making during the stay-at-home period.

While some people have begun to utilize local food businesses instead of the supermarket, others have been motivated by their pandemic experience to explore, plan and plant food gardens for household use located in their yards or boulevards. Victory Gardens, also termed crisis gardens by food historian Rose Hayden-Smith (Helmer 2020) tend to be forgotten by governmental organizations and the general population alike during peacetime. Rooted in the history of developed nations across the globe, crisis gardens are a fact of life for many in developing nations. Hayden-Smith notes that gardening empowers people, allowing them to have 
" "control in a situation that feels entirely out of control"" (Helmer 2020), and "free[dom] from the oppression presented by hunger, obesity, and lack of community engagement" (Hayden-Smith 2014, p. 26). Theses gardens build self-efficacy, reflect personal food choices, and restore food sovereignty. While gardening has typically been a popular hobby across the U.S., fewer than half of gardeners report gardening for food access and fewer than a quarter report doing so for economic reasons (McFarland et al. 2018) both of which are likely to be primary reasons for the surge seen during Covid-19.

Because of our lack of preparation as a nation, some new gardeners experience difficulty obtaining the supplies needed to start a garden. As seed sales surge, many seed companies are experiencing shortages like supermarkets with prolonged delays in shipping and some even closing temporarily to either all purchases or home-gardeners only (Johnny's Selected Seeds 2020; Seed Savers Exchange 2020; Pierre-Louis 2020). While interest in home gardening has increased dramatically, it is not clear if these seed purchases will result in an actual increase in food grown at home or if they are another manifestation of people stocking up unnecessarily and without actual use. It is also unknown whether people had knowledge and skills to successfully garden. Coinciding with the surge in sales, some states (including Michigan) have temporarily restricted the sale of non-essential items including home and garden items, such as seeds, as non-essential. Others have declared retail plant nurseries as non- essential businesses, even as it recognizes agriculture (defined as those producing commodities as opposed to specialty crops) as essential (Galloway 2020). This paradox compounds the difficulties faced by home growers, particularly new home growers wishing to assert some control over their food system.

Although more resilient, existing local farms have also experienced difficulty in the pandemic. For example, local farms and their partners in Michigan, including those in the hardest hit area of Detroit, retooled their budgets, crops, and markets to serve their local communities during the pandemic period (Boldrey 2020b; Houck 2020). Some farms have shifted to increase food-donations while pantries and local farms have worked to establish partnerships to facilitate low-cost farm-to-pantry purchasing (Barnes 2020; West Michigan Growers Group 2020). In Port Huron, the local government has partnered with a local gardening store to distribute fruit and vegetable seeds to families-in-need (Smith 2020). Many farmers attempting to pivot their businesses continue to struggle to navigate the challenge of an uncertain future by both growing crops for local communities and for the restaurant industry, anticipating that business will return at some point during the growing season. Government intervention, through the USDA, stepped in with policy changes that assisted farmers including farm boxes and free school meals.

From the time of the lifting of the stay-at-home to the time of effective treatment, or vaccine-induced herd immunity, we live in uncertainty. Fears of another surge may recycle the stages of food behavior resulting once more in over- shopped supermarkets with consistently empty shelves and new behaviors may emerge. Some of what was learned will ease anxiety during surges, and long into the future if, or when, we see this virus or another pandemic again. The resilience and empowerment of living through a pandemic will make us better able to act through the lens of life satisfaction and life meaning which could translate to more concern for those around us (Arslan et al. 2021). Prepared home pantries, not ones that exhibit hoarding, more acceptance of canned foods, more access to personally or locally grown fresh foods, and more personal autonomy during dependence are elements that may persist as we continue to live with Covid-19.

\section{A new normal?}

Looking ahead, people are starting to imagine how daily lives will be transformed once the high-risk stages of the pandemic are over, as we adjust to a new normal of living after proven infectious disease intervention is available and as life continues post-pandemic. Many questions about foodways will be transformed by this time and whether such changes will persist. Some of this depends upon how and what kind of interventions emerge. Will the food experiences and efforts to regain control during the pandemic result in a transformative new normal with long-term persistence? Or will the pandemic result in exhaustion, with people rebounding to rely even more heavily on "convenient" industrial foods?

While the pandemic demonstrates the critical importance of a resilient food system that can flexibly respond to crises in the moment without the loss of sovereignty or justice (Hayden-Smith 2014; Rice et al. 2020), whether changing individual practices will result in a larger system transformation is yet to be seen. Although during the pandemic, many individuals, businesses, and communities have taken steps toward transformation while they attempt to gain control, there is no clear evidence that these attempts will result in broad and sustainable change after the pandemic, or in a just system.

\section{Resiliency in the food system}

As pandemic life unfolds from within kitchens, home offices and living rooms, there are clear indications that people in many social locations are newly aware of their vulnerabilities 
in the industrial food system. Looking carefully at the food world as it bares itself around us, we see immense vulnerability not only among the already marginalized, but also among the working and middle classes as they distance in the grocery store aisles, order up home food delivery, don masks and sanitize their carts, face widespread unemployment, and visit free school lunch drop-off sites and food pantries in unprecedented numbers. It is not just the demand for toilet paper-even those who have, cannot have enough flour, enough kale, enough vitamins, enough garden seeds. Many feel angry, scared, and powerless (Catchings 2020).

Developing just, place-based food systems that value political sovereignty, cultural integrity, and ecological resilience, is a slow, steady project to empower all people by returning the control of food to the eaters instead of food corporations. Paying careful attention to how people negotiate their food relationships during this crisis can lead to new insights, and to important understandings about how an unjust food system harms all its members, whether their pantries are bare or not. As people live through this pandemic, and as communities negotiate changing food systems, the importance of diversity and resilience to food sustainability become clearer and clearer. We must identify "new paths to a new normal grounded in more sustainable, resilient and just forms of agriculture" (Sanderson 2020, p. 516). The experience of pandemic demonstrates the importance of a shift toward a food system that prioritizes food sovereignty, sustainability, diversity and resiliency within communities and supply chains (Altieri and Nicholls 2020; Blay-Palmer et al. 2020; Darnhofer 2020; Emmad and Pena 2020; Gleissman 2020; Imhoff 2020; Nabhan 2020; Prokopy et al. 2020; Richardson 2020).

In modern industrial food systems, lean management is the goal, and redundancy is seen as waste. In other words, things must happen "just in time," without duplication and without variation. Just-in-time inventory management systems are used to avoid waste by producing items to meet demand at the time of the demand, and not in advance (Pinta et al. 2018). People are dependent upon obtaining food within systems where farmers grow single crops, and sell them to single buyers, and these foods make their way through a chain of production to the supermarket where they are sold at a significant markup. This system is heavily dependent upon profit-oriented, just-in-time inventory management with long supply chains, forcing our collective dependency upon food producers and distributors.

Modern, industrial food systems cannot adequately address the anxiety of the unknown experienced during a crisis. They require either responsive production or accurate forecasting, neither of which are effective during times of unpredictable crisis such as the Covid-19 pandemic (Hendrickson 2020). These systems have, in fact, failed consumers as on-the-shelf food shortages have been experienced across Michigan, the United States, and the world, mimicking historical food shortages that eventually led to a massive overhaul of the U.S. farm policy in favor of industrialization during the 1970s. Just-in-time management systems cannot forecast the unprecedented pandemic induced food behaviors that shook the system while driving people to shop more heavily than before. While many in the food industry claim these shortages are short-term, some evidence points to a longer-term shortages, including concerns over supply shock and logistics (Munshi and Almeida 2020), reports of sick front-line workers (Coolidge 2020; McVicar 2020), and the closing of large food processing plants due to sick workers (Lardieri 2020; Soucheray 2020) leading to a surge in the utilization of local food systems (i.e., local butcher shops, local grain millers, and home gardens) as people attempt to cope with their long-term food fears (Domol 2020; Halloran 2020; Helmer 2020). Similarly, just-in-time management systems cannot respond with increased production to accommodate consumer needs when workers become sick and the industrial supply has been stalled.

These newly visible failings of our food system are the result of a lack of resilience in the industrialized supply. Resiliency, the ability of "systems to absorb change" and "still persist" (Holling 1978, p. 17), adapt, and continue to develop (Folke 2006; Lake et al. 2019), is the hallmark of sustainable food systems. Resiliency requires redundancy and diversity (Kotschy et al. 2015), two values that run contrary to the principles of popular lean business methodologies (da Silva et al. 2019; White 2019). Diversity is a critical value to resilient food systems in multiple ways: ecological diversity (i.e., a diversity of plants and animalscrops and pollinators), cultural diversity (i.e., a diversity of kinds of food for a diversity of kinds of people), and economic diversity (i.e., a diversity of ways of distributing food among people). The ability of community farms to pivot budgets and business models is a direct result of diverse knowledge- bases, diverse values, diverse relationships, and diverse customer-bases. Multiple entities doing the same work, though redundant, is not waste- together a myriad of local food producers are ensuring the work of feeding communities continues despite the myriad challenges Covid-19 presents to the industrial system. Moreover, redundancy is not seen as waste in resilient systems. Instead, redundancy is viewed as connective tissue, helping to meet needs by allowing for the reorganization of the system in the face of interruptions, thereby successfully navigating uncertainty and crises (Folke 2006). 


\section{Food as a currency of power: autonomy and sovereignty}

The well-developed critical conversations among scholars and activists about food security, autonomy, sovereignty, and resiliency are critical in understanding these events in Michigan. Food security is the ability of people to have "access to sufficient, safe, nutritious food to maintain a healthy and active life" (World Health Organization 2015 in LeBlanc \& Burnett 2017, p. 16), and this focus on meeting basic physical needs characterizes much large-scale government and NGO work. Food activists, especially those working from within community organizing, argue for a more nuanced approach to food choice as it is bound up in relations of political and economic power. In this view, a simple expansion of the current food system to meet the needs of all is insufficient - the system itself must be transformed. In this context, food autonomy is the ability of individuals and local groups to determine their own foodways. Food autonomy is about food choice. People must have the ability to choose their own food based on personal beliefs and local knowledge about health, sustainability, and culture. Food sovereignty includes and goes beyond food security and autonomy. Food sovereignty is the overarching ability of communities to develop and govern their own food systems in ways that foster culturally, socially, nutritionally, and politically appropriate foodways. Since food is a source of power and dependency, food sovereignty demands that eaters, not corporations, control food systems. When eaters control their food systems they are empowered with knowledge and physical resources to craft their own food environments-to growing food or having existing relationships with the people who do grow food-rather than being subject to the supply of the corporate environment. The pandemic has disrupted food security and food autonomy broadly, and many people are experiencing these disruptions across social, cultural and class groups. While many of these people are attempting to create food security and autonomy for themselves through home gardens, local buying, and other strategies, it should not take a pandemic with mass unemployment and stay-at-home orders for people to have the time and energy to maintain home gardens, or for communities to broadly support one another. The pandemic demonstrates the need for larger transformations in the food system itself; for movement away from industrial food systems and towards systems that prioritize local wellbeing, food access, food autonomy and food justice over corporate profit.

In 1996 members of the Via Campesina movement articulated their influential definition of food sovereignty, which continues to shape food sovereignty activism 25 years later:
Food sovereignty is the right of peoples to healthy and culturally appropriate food produced through sustainable methods and their right to define their own food and agriculture systems. It develops a model of smallscale sustainable production benefiting communities and their environment. It puts the aspirations, needs and livelihoods of those who produce, distribute and consume food at the heart of food systems and policies rather than the demands of markets and corporations. Food sovereignty now appears as one of the most powerful responses to the current food, poverty and climate crises. (La Via Campesina 2015 in Robidoux \& Mason 2017, p. 14)

Food sovereignty is an active, fluid concept that shifts and changes with the work. For example, in their recent work exploring Indigenous food practices in rural and remote Northern Ontario, LeBlanc and Burnett (2017) argue that food sovereignty must meaningfully address "the diversity of human food systems, as well as the social meanings and relationships that different peoples and cultures have with their food and foodways, including those traditions that are central to the production and preparation of food" (p. 18). For example, extensive evidence suggests that people who feel empowered through gardening programs feel increased self-efficacy and locus of control (Aguilar et al. 2008; Cohen 2018; Hoffman and Wallach 2005; Hoffman et al. 2007; Jenkins 2016; Pierce 2007). In a food system that emphasizes sovereignty, where people therefore experience increased self-efficacy and locus of control, we expect there would be a reduction in the anxiety and dependency induced food behaviors described above, and less stress therefore on the overall food system (and the people who participate in it) during pandemics.

Food activists have been working for decades to transform food systems, to rebuild local, place-based, or community controlled foodways in the context of power relations which favor industrial food and agriculture. In this context, the focus has rightfully been on those communities which are disenfranchised from the global industrial food system, most often Indigenous, African American, Latinx, and other communities of color who are most vulnerable in a racialized society. All indications are that the impact of Covid-19 in these communities is exponentially greater than in white communities, particularly in Michigan where communities are highly segregated and access to food, health care, and other necessities of life is not equally (or equitably) available to all. While marginalized communities experience exponentially greater impacts than those in the center, we observe changes in food behaviors across many segments of Michigan society, suggesting to us that in fact everyone is vulnerable in a food system that prioritizes capitalist margins. The experience of the pandemic makes even more clear 
that the longstanding power imbalances of our current food system do not work for most people who participate in the system, demonstrating that in times of crisis, an unjust system betrays all who rely upon it.

\section{An aspirational new normal: toward just and sustainable food systems}

Pandemic induced food behaviors within our communities demonstrate the vulnerability everyone faces in our industrial food system. Many of the food challenges that have long impacted under-resourced communities have been felt more broadly across the working and middle classes as people are unable to travel to acquire food, confront lack of availability and increased cost of their preferred foods, become unemployed and unable to purchase food as usual, or are required to provide more meals per day than previously. The often unseen impact of a lack of diversification and resilience in the food system - an underappreciation of diverse knowledge bases, low diversity of crops grown, low diversity in the method of obtaining food-becomes apparent far more broadly, as Rice et al. (2000) have pointed out. Part of what this experience brings to light is the importance of a robust approach to sustainable food systems, an approach that embodies diversity and redundancy in multiple ways (ecological, cultural, economic) and at multiple levels (growing, selling, cooking, eating). A robust food system fosters food autonomy and sovereignty and prioritizes resilience and diversity over efficiency.

For many who describe their food practices as sustainable, this is true only in the slimmest sense. Levkoe (2011) extensively documents the criticism against local food initiatives' abilities to transform the system into a just one for all, noting that they all operate within a capitalist, profit-oriented framework, and these criticisms persist amid the pandemic. Farmers who grow a few organic crops, such as those who grow only lettuce and tomatoes, or only fava beans, for sale to a single purchaser such as a restaurant are practicing slim sustainability. This is true, for example, of those high-profile members of the 'Farm to Table Movement' highlighted in the New York Times whose farms are replete with valuable crops they can no longer sell (Severson 2020). Although their foods are grown without pesticides and sold locally, they lack the robust commitment to diversity of crops and markets and are without connection to their own diverse local communities. These farms find themselves at risk of failure during the pandemic. Industrial food systems and those practicing slim sustainability leverage economies of scale, leaving them heavily invested in the infrastructure to service only one or two models of production and distribution. Having prioritized single systems to increase efficiency and profit, they are unable to quickly pivot and adapt, and in the pandemic, they are selling livestock and dumping crops (Severson 2020). Practices of slim sustainability have left the food system unchanged and demonstrate the lack of resilience slim models of sustainability produce. In times of profound stress, practitioners of slim sustainability are as unable to pivot, as are most eaters in the industrial food system.

Farms and food producers who practice robust sustainability are better positioned to understand the needs of and serve their local communities. Small farms that practice robust sustainability can pivot in response to local food emergencies as they are less heavily invested in the infrastructure in service to a single model of production and distribution. For example, the Grand Valley State University Sustainable Agriculture Project traditionally produces a large diversity of crops, but heavily relied on student interns to produce high turnover crops such as lettuce and radishes, and space-saving but labor-intensive single-stemmed tomatoes, but was left with only a single worker, the farm manager, when the university closed under the Michigan stay-at-home order. This small (4-acre) farm pivoted their model of production to include more longer season crops, requiring less labor. Furthermore, while the students, faculty, and staff who typically are their customers were away from the university, the farm was able to donate the produced foods to local food justice organizations that have existing relationships with families in need. A much larger neighboring farm, Visser Farms, a family-owned farm since 1902, typically sells their produce at farmers markets, through a CSA, and directly to a variety of local restaurants. With restaurants closed for an extended period, this farm began operating pop-up farmer's markets throughout the region, selling its produce directly in venues that allow for easy physical distancing. In both cases these farms were able to draw on expertise, relationships, and farm practices that were already a component of their work, focusing more heavily on crops and distribution practices that fit the quickly changing context. Similarly, online farmers' markets, such as Market Wagon (2021), facilitated small farmers' pivots during the pandemic by partnering with them to provide an online ordering platform and delivery service. Market Wagon saw an expansion into West Michigan in June 2020 (Market Wagon West Michigan 2020). Although these types of businesses facilitate farm to consumer access, they do not necessarily facilitate a more just and equitable food system.

The pandemic exposes the false sense of security at many places in the industrial food system, particularly those in the middle class. It also exacerbates the challenges facing those who live in poverty, in food insecure contexts, and in segregated and racialized neighborhoods. While utilizing local food systems, growing home gardens, and shifting farm business models can be foundational for food security and autonomy for some, they are not enough to transform the system. The experiences of the most marginalized 
communities in our state are also the most hidden-the challenges faced by those without enough money or access to land, without private transportation, without access to food or health care, with limited health literacy, and without access to internet-are deep and complex, and not easily illuminated mid-pandemic. People living in Detroit, Flint and Grand Rapids, Michigan, where these issues are highly prevalent, are among the most vulnerable to the novel coronavirus in the United States. Michigan data clearly shows that Covid-19 has disproportionately affected racialized people in the state (State of Michigan 2020). Critically important questions remain about the impact of food injustice on the experience of the Covid-19 pandemic in marginalized and racialized communities. For some, lack of access to affordable healthy food factors into health outcomes and may be a critical factor in infection and death rates during the pandemic (Alkon et al. 2020). The additional work that some must do to get food, such as traveling long distances on public transit, may further affect their likelihood to contract the virus.

Activists already involved in community farms and gardens serving under-resourced populations provide insight into how place-based food systems, that prioritize personal food autonomy and community food sovereignty, could have helped alleviate the pandemic induced food behaviors seen during Covid-19. In these projects, local autonomy and justice have long been a part of the core mission every day. These farms and gardens are viewed as a source of empowerment for individuals and food system resiliency. White (2018) documents the way participants of Detroit-based D-Town Farms view the work they do as "political because it puts control in [our] hands. We won't have to live from someone else's hands, and neither will [our] children when they learn to grow their own food" (p. 133). When people feel empowered by their food systems rather than dependent on the food system, the first two stages of the pandemic induced food behaviors-anxiety of the unknown and new dependency — may be mitigated.

Looking back at the community resiliency projects developed by Freedom Farm Cooperatives during the 1960s and 1970s provides insight on the undercurrent paradigm in the industrial food system and on how a just, place-based food system might resolve the problems experienced during Covid-19. Monica White (2018) documents three strategies that led to the success of these cooperatives, "commons as praxis, prefigurative politics, and economic autonomy" (p. 145) which ultimately led to "collective agency and community resilience." In other words, activism at multiple levels is necessary. To be transformative, a community-based rather than an individualized approach is essential-including the sharing of seeds, equipment, knowledge, and space. A community-based approach coupled with the deep understanding of food as a political and economic tool (i.e., as a system of power) with community, state, and national policies to resource a just system can help this transformation manifest. Drawing on a diversity of relationships between local farmers and the eating public by valuing the social and ecological ties within a community, we can collectively plan for a diverse set of future possibilities. The pandemic food experience means that the challenges of the industrial food system are felt broadly across the population, including among those who are normally insulated from its injustices. This broadly shared experience creates the potential to catalyze change to ensure a more secure food future for everyone. Transforming our industrial food system into one characterized by autonomy, sovereignty, diversity, and resilience is critical work, clarified by the experience of eating in a pandemic.

The long-term impact of Covid-19 on the food justice and sustainability movement remains to be seen. Now that many middle-class Americans have experienced the failings of the global, industrialized food system, will there be a larger momentum toward robust sustainable changes? A new normal may persist, where many more people enact a more intentional approach to buying, eating, and even growing their own food, with a growing commitment to transformation of the larger food system. Food sovereignty should, and could, become a public priority. New social norms arising from the pandemic experience could have a sustained transformative effect on the status quo (Burns 2014; Lake et al. 2019; Stahel 2016), so that food autonomy and sustainability become seen not as a luxury for few, but as a necessity for all people, all the time. There is clearly some distance to go.

Further exploration of people's experiences with the food system is needed to best understand whether and how this pandemic in an industrialized nation is shifting values, attitudes, and behaviors. Further research will be needed to understand if new and growing practices such as widespread accessing of local food systems, seed purchases, and the pivoting business models of food producers are the start of a new normal, or if they were simply other manifestations of anxiety and vulnerability that will be quickly abandoned once the Covid-19 pandemic ends. Activism and policy are needed to ensure any transformation in the food system is inclusive and equitable for all. The industrial food system will not change itself. Will new food behaviors speed us to a transformative tipping point? The pandemic demonstrates that we must act towards food justice. Though many aspire to a permanent shift towards food equity, sovereignty, and sustainability, only with challenging work and a broad wave of engagement can effective, practical change be generated in people's food lives.

Acknowledgements Thanks to Kirsten Rydzewski for her critical editorial skills, and to the Wabash Center for Teaching and Learning for their support of the Growing Diversity Project at the GVSU Sustainable Agriculture Project. Thanks to our GVSU colleagues and conversation partners including those in Environmental \& Sustainability Studies, 
Allied Health Sciences, The GVSU Center for Scholarly and Creative Excellence, Integrative Religious and Intercultural Studies, The Frederik Meijer Honors College and The Sustainable Agriculture Project, and particularly to our collaborators in the Growing Diversity Project: Jason Herlands, Kelly Parker, Santos Ramos, Brent Smith, Deana Wiebel, Justine Kibet, Kristen Rydzewski and Erica Ramos.

\section{References}

Aguilar, O.M., T.M. Waliczek, and J.M. Zajicek. 2008. Growing environmental stewards: The overall effect of a school gardening program on environmental attitudes and environmental locus of control of different demographic groups of elementary school children. HortTechnology 18 (2): 243-249. https://doi.org/10. 21273/HORTTECH.18.2.243.

Akhtar, S. 2019. Hoarding: A multifactorial understanding. International Journal of Applied Psychoanalytic Studies 16 (3): 145-159. https://doi.org/10.1002/aps.1626.

Alkon, A.H., S. Bowen, Y. Kato, et al. 2020. Unequally vulnerable: A food justice approach to racial disparities in COVID-19 cases. Agriculture and Human Values 37: 535-536. https://doi.org/10. 1007/s10460-020-10110-z.

Altieri, Miguel A., and Clara I. Nicholls. 2020. Agroecology and the reconstruction of a post-COVID-19 agriculture. The Journal of Peasant Studies 47 (5): 881-898. https://doi.org/10.1080/03066 150.2020.1782891.

Arslan, G., M. Yildırım, and M.M. Leung. 2021. Mediating effect of personal meaning in the prediction of life satisfaction and mental health problems based on coronavirus suffering. Frontiers in Psychology 12: 638379. https://doi.org/10.3389/fpsyg.2021.638379.

Barnes, D. 2020. Produces from GVSU educational farm will be donated throughout growing season.GVNext https://www.gvsu. edu/gvnext/2020/produce-from-gvsu-educational-farm-will-bedonated-11456.htm. Accessed 30 May 2020.

Bell, E. 2020. Demand for CSAs and local produce surge in the face of COVID-19. New Jersey Monthly. https://njmonthly.com/artic les/eat-drink/table-hopping/farms-csas-coronavirus-nj/. Accessed 30 May 2020.

Blay-Palmer, A., R. Carey, E. Valette, and M.R. Sanderson. 2020. Post COVID 19 and food pathways to sustainable transformation. Agriculture and Human Values 37: 517-519. https://doi.org/10.1007/ s10460-020-10051-7.

Boldrey, R. 2020a. Michigan National Guard expands food bank assistance amid coronavirus crisis. MLive. https://www.mlive.com/ news/2020/04/michigan-national-guard-expands-food-bank-assis tance-amid-coronavirus-crisis.html. Accessed 20 April 2020

Boldrey, R. 2020b. Family dairy farm finds way to thrive while others struggle. MLive. https://www.mlive.com/coronavirus/2020/04/ family-dairy-farm-bucks-coronavirus-trend-as-business-booms. html. Accessed 30 April 2020.

Booth, S., A. Begley, B. Mackintosh, D.A. Kerr, J. Jancey, M. Caraher, and C.M. Pollard. 2018. Gratitude, resignation and the desire for dignity: Lived experience of food charity recipients and their recommendations for improvement, Perth, Western Australia. Public Health Nutrition 21: 2831-2841. https://doi.org/10.1017/S1368 980018001428.

Burns, D. 2014. Assessing impact in dynamic and complex environments: Systemic action research and participatory systemic inquiry. Centre for Development Impact: Practice Paper 8: 1-10.

Catchings, C. 2020. Confronting feelings of powerlessness during the Coronavirus outbreak. Talkspace. https://www.talkspace.com/ blog/coronavirus-powerlessness-feelings-managing-anxiety/. Accessed 13 September 2021.
Chong, D., and J.N. Druckman. 2007. Framing theory. Annual Review of Political Science 10: 103-126.

Cohen, J.E. 2018. Colorful gardens and empowerment: Black resistance and self-determination through urban farming. Standard Theses. 168. https://scarab.bates.edu/cgi/viewcontent.cgi?artic le $=1168 \&$ context $=$ envr_studies_theses. Accessed 20 April 2020.

Coolidge, A. 2020. Four Kroger workers die after falling ill with covid-19. Cincinnati Enquirer. https://www.cincinnati.com/story/ money/2020/04/13/coronavirus-four-kroger-workers-die-after-falli ng-ill/2984964001/. Accessed 30 May 2020.

Cresswell, John. 2012. Qualitative inquiry and research design: Choosing among five approaches, 3rd ed. London: Sage Publications.

da Silva, I.B., M.G. Filho, O.L. Agostinho, and O.F. Lima. 2019. A new Lean Six Sigma framework for improving competitiveness. Acta Scientarium: Technology 41: e3732. https://doi.org/10.4025/ actascitechnol.v41i2.37327.

Darnhofer, I. 2020. Farm resilience in the face of the unexpected: Lessons from the COVID-19 pandemic. Agriculture and Human Values 37: 605-606. https://doi.org/10.1007/s10460-020-10053-5.

Davidson, E.J., M.E. Dozier, J.O.E. Pittman, T.L. Mayes, B.H. Blanco, J.D. Gault, and C.R. Ayers. 2019. Recent advances in research on hoarding. Current Psychiatry Reports 21 (9): 1-9. https://doi.org/ 10.1007/s11920-019-1078-0.

Domol, J. 2020. Butcher shop sees business increase amid pandemic. WoodTV. https://www.woodtv.com/health/coronavirus/butchershop-sees-business-increase-amid-pandemic/. Accessed 4 June 2020 .

Emmad, F., and D.G. Peña. 2020. Feeding our autonomy: Resilience in the face of the CoVid-19 and future pandemics. Agriculture and Human Values 37: 565-566. https://doi.org/10.1007/ s10460-020-10074-0.

Folke, C. 2006. Resilience: The emergence of a perspective for socialecological systems analyses. Global Environmental Change 16: 253-267.

Fook, J. 1999. Reflexivity as method. Annual Review of Health Social Sciences 9: 11-20.

Gardner, P. 2020. Depression-level' Michigan unemployment tops 1 million from coronavirus. Bridge. https://www.bridgemi.com/ economy/depression-level-michigan-unemployment-tops-1-milli on-coronavirus. Accessed 30 April 2020.

Galloway, M. 2020. Garden centers, greenhouses to Gov. Whitmer: 'We doubt we will survive.' Michigan Farm Bureau. https://www.michi ganfarmnews.com/garden-centers-greenhouses-to-gov-whitmerwe-doubt-we-will-survive. Accessed 15 September 2021.

Glengariff Group. 2020. Michigan General Population Survey COVID19. https://drive.google.com/file/d/1W7DV9P_Wql-NR9jqAEL_ cXpPe2AfKsmt/view. Accessed 30 April 2020.

Gliessman, S.R. 2020. Transforming food and agriculture systems with agroecology. Agriculture and Human Values 37: 547-548. https:// doi.org/10.1007/s10460-020-10058-0.

Halloran, A. 2020. Flour shortage? Amber waves of regional grains to the rescue. Civil Eats. https://civileats.com/2020/04/24/flour-short age-amber-waves-of-regional-grains-to-the-rescue. Accessed 30 May 2020.

Harvey, D. 2005. Spaces of global capitalism: A theory of uneven geographic development. New York, NY: Verso.

Harvey, D. 2012. Rebel cities: From the right to the city to the urban revolution. New York, NY: Verso.

Hastings, M. 2020. 45-year-old butcher shop is busier than ever during coronavirus pandemic. Winston- Salem Journal. https://www. greensboro.com/entertainment/dining/45-year-old-butcher-shopis-busier-than-ever-during-coronavirus-pandemic/article_e4ec9 6ed-4b77-5bc9-bfde-48899421dcb6.html. Accessed 30 May 2020.

Hayden-Smith, R. 2014. Sowing the seeds of victory: American gardening programs of World War I. Jefferson, NC: McFarland. 
Helmer, J. 2020. How the coronavirus pandemic has led to a boom in crisis gardening. HuffPost. https://www.huffpost.com/entry/ seeds-crisis-gardening-coronavirus-food_n_5e85eca0c5b6f55 ebf492212. Accessed 30 May 2020.

Helton, J.J., J.C. Schreiber, and B.H. Fiese. 2017. Foster parents' nutritional strategies and children's well- being. Child and Adolescent Social Work Journal 34: 159-169.

Hendrickson, M.K. 2020. Covid lays bare the brittleness of a concentrated and consolidated food system. Agriculture and Human Values 37: 579-580. https://doi.org/10.1007/s10460-020-10092-y.

Holling, C.S. 1978. Adaptive environmental assessment and management. New York: Wiley.

Houck, B. 2020. How Detroit's urban farming community is coping with coronavirus restaurant closures. Eater Detroit https://detro it.eater.com/2020/3/31/21199525/detroit-urban-farms-restaurantclosures-coronavirus-covid-19. Accessed 30 May 2020.

Hoffman, A.J., and J. Wallach. 2005. Effects of mentoring on college students in transition to university. The Community College Enterprise 11: 67-78.

Hoffman, A.J., L.F. Morales Knight, and J. Wallach. 2007. Gardening activities, education, and self- esteem: Learning outside the classroom. Urban Education 42: 403-411.

House, K. 2020. A Michigan school bus turns food truck during coronavirus school shutdown. Bridge. https://www.bridgemi.com/talent-education/michigan-school-bus-turns-food-truck-during-coron avirus-school-shutdown. Accessed 21 April 2020.

Imhoff, D. 2020. Lessons of dislocation. Agriculture and Human Values 37: 637-638. https://doi.org/10.1007/s10460-020-10095-9.

Jenkins, R. 2016. Landscaping in lockup: The effects of gardening programs on prison inmates. https://scholarworks.arcadia.edu/ cgi/viewcontent.cgi $?$ article $=1005 \&$ context $=$ grad_etd Accessed May 30, 2020.

Johnny's Selected Seeds. 2020. A message to Johnny's customers about COVID-19. https://www.johnnyseeds.com/customer-support/ covid-19-message.html. Accessed 30 May 2020.

Kotschy, K., R. Biggs, T. Daw, C. Folke, and P. West. 2015. Principle I: Maintain diversity and redundancy. In Principles for building resilience: Sustaining ecosystem services in socio-ecological systems, ed. R. Biggs, M. Schlüter, and M.L. School, 50-79. Cambridge: Cambridge University Press.

Lake, D.L., A.L. McFarland, and J.L. Vogelzang. 2019. Resilient interventions to food waste. In Food waste management: Solving the wicked problem, ed. E. Närvänen, N. Mesiranta, M. Mattila, and A. Heikkinen, 193-224. Cham: Palgrave Macmillan.

Lakhani, N. 2020. 'A perfect storm': US facing hunger as demand for food banks soars. The Guardian. https://www.theguardian.com/ environment/2020/apr/02/us-food-banks-coronavirus-demandunemployment. Accessed 21 April 2020.

Lardieri, A. 2020. Smithfield Foods closes plant after nearly 300 employees test positive for coronavirus. U.S.News. https://www. usnews.com/news/national-news/articles/2020-04-13/smithfieldfoods-closes-south-dakota-processing-plant-after-employees-testpositive-for-coronavirus. Accessed 30 April 2020.

LeBlanc, J., and K. Burnett. 2017. What happened to indigenous food sovereignty in northern Ontario? Imposed political, economic, socio-ecological and cultural systems changes. In A land not forgotten: Indigenous food security \& land-based practices in Northern Ontario, ed. M.A. Robidoux and C.W. Mason, 16-33. Winnipeg: University of Manitoba Press.

Lefebvre, H. 2014. Critique of Everyday Life. (J. Moore, Trans.). New York, NY: Verso. (1977).

Levkoe, C.Z. 2011. Towards a transformative food politics. Local Environment 16: $687-705$.

Market Wagon. 2021. About Us. https://marketwagon.com/pages/ market-wagon-about-us
Market Wagon West Michigan. 2020. https://www.facebook.com/ MarketWagonWestMI/posts/117372120002487. Accessed 30 May 2020.

Mathison, S. 1988. Why triangulate? Educational Researcher 17 (2): 13-17.

McFarland, A., T.M. Waliczek, C. Etheredge, and A.J. SommerfeldLillard. 2018. Understanding motivations for gardening using a qualitative general inductive approach. HortTechnology 28: 289-295.

McVicar, B. 2020. Meijer employee tests positive for coronavirus at West Michigan store. MLive. https://www.mlive.com/news/grandrapids/2020/04/meijer-employee-tests-positive-for-coronavirus-atwest-michigan-store.html. Accessed 30 April 2020.

Munshi, M., and I. Almeida. 2020. There's plenty of food in the world, just not where it's needed. Bloomberg. https://www.bloomberg. com/news/articles/2020-03-19/the-fragile-system-supplying-foodto-the-world-is-under-strain. Accessed 30 April 2020.

Nabhan, G.P. 2020. Crops from U.S. food supply chains will never look nor taste the same again. Agriculture and Human Values 37: 651-652. https://doi.org/10.1007/s10460-020-10109-6.

Nielsen. 2020. Key consumer behavior thresholds identified as the coronavirus outbreak evolves. https://www.nielsen.com/us/en/insig hts/article/2020/key-consumer-behavior-thresholds-identified-asthe-coronavirus-outbreak-evolves/. Accessed 22 February 2020.

O'Sullivan, T.L., and K.P. Phillips. 2019. From SARS to pandemic influenza: The framing of high-risk populations. Natural Hazards 98: 103-117. https://doi.org/10.1007/s11069-019-03584-6.

Pierce, C.A. 2007. For a moment I feel free: Homeless women and a garden-based learning program. PhD diss. University of Tennessee, 2007. https://trace.tennessee.edu/utk_graddiss/266. Accessed 30 April 2020.

Pierre-Louis, K. 2020, March 28. Panic buying comes for the seeds. New York Times. https://www.nytimes.com/2020/03/28/style/seedpanic-buying-coronavirus.html. Accessed 30 April 2020.

Pinta, J.L.Q., J.C.O. Matias, C. Pimental, S.G. Azevedo, and K. Govindan. 2018. Just in time factory: Implementation through lean manufacturing tools. Cham: Springer.

Preston, S. 2020. Hoarding is not a strange behavior during times of crisis. University of Michigan News. https://news.umich.edu/hoard ing-is-not-a-strange-behavior-during-times-of-crisis/. Accessed 1 April 2020.

Prokopy, L.S., B.M. Gramig, A. Bower, et al. 2020. The urgency of transforming the Midwestern U.S. landscape into more than corn and soybean. Agriculture and Human Values 37: 537-539. https:// doi.org/10.1007/s10460-020-10077-x.

ready.gov. 2021. Winter weather. https://www.ready.gov/winter-weath er. Accessed 3 March 2021.

Rice, C.W., R. Schoen, A. Aristidou, S.C. Burgess, S. Capalbo, G. Czarnecki-Maulden, and V.A. Sample. 2020. Keeping up with the fast-moving world of crisis management. Agriculture and Human Values 37: 531-533. https://doi.org/10.1007/s10460-020-10045-5.

Robidoux, M.A., and C.W. Mason. 2017. Collaborative responses to rebuilding local food autonomy in three indigenous communities in Northwestern Ontario. In A land not forgotten: Indigenous food security \& land-based practices in Northern Ontario, ed. M.A. Robidoux and C.W. Mason, 51-84. Winnipeg: University of Manitoba Press.

Richardson, R. 2020. Bending the arc of COVID-19 through a principled food systems approach. Agriculture and Human Values 37: 653-654. https://doi.org/10.1007/s10460-020-10048-2.

Sanderson, M.R. 2020. Here we are: Agriculture and human values in the coronavirus (COVID19) pandemic. Agriculture and Human Values 37: 515-516. https://doi.org/10.1007/ s10460-020-10040-w.

Seed Savers Exchange. 2020. Covid 19 Statement. https://www.seeds avers.org/covid-19-statement. Accessed 30 May 2020. 
Severson, K. 2020. The farm-to-table connection comes undone. New York Times https://www.nytimes.com/2020/04/09/dining/farm-totable-coronavirus.html. Accessed 30 May 2020.

Shaeffer, M. 2017. The social context of hoarding behavior: Building a foundation for sociological study. Sociology Compass 11 (4): e12472. https://doi.org/10.1111/soc4.12472.

Smith, D.E. 1987. The everyday world as problematic: A feminist sociology. Boston: Northeastern University Press.

Smith, J. 2020. City program offering 1,000 seed packets at no cost for residents to grow veggies at home. Times Herald. https://www. thetimesherald.com/story/news/2020/04/21/free-seed-packetshelp-port-huron-residents-grow-veggies-home/2996895001/. Accessed 30 May 2020.

Snyder, G. 2020. Roasts, braises and ground beef: Butcher shops are seeing a huge spike in meat sales. Los Angeles Times. https:// www.latimes.com/food/story/2020-03-23/butcher-shop-coron avirus-sales. Accessed 30 May 2020.

Soucheray, S. 2020. US food processing plants become COVID-19 hot spots. University of Minnesota Center for Infectious Disease Research and Policy. https://www.cidrap.umn.edu/news-persp ective/2020/04/us-food-processing-plants-become-covid-19-hotspots. Accessed 30 May 2020.

Stahel, W.R. 2016. Circular economy. Nature 531: 435-438.

State of Michigan. 2020. "Governor Whitmer Signs Executive Order Creating the Michigan Coronavirus Task Force on Racial Disparities." https://www.michigan.gov/whitmer/093097-387-90499526478-00.html. Accessed 13 September 2021.

Streams of Hope. 2020. Food center remains open during COVID-19. https://streamsofhope.org/2020/04/07/food-center-remains-openduring-covid-19/. Accessed 15 April 2020.

United States Department of Agriculture. 2020. USDA Makes it Easier to Feed Kids and Those Who Need Food During the COVID-19 National Emergency. https://www.usda.gov/media/press-releases/ 2020/03/26/usda-makes-it-easier-feed-kids-and-those-who-needfood-during-covid. Accessed 30 May 2020.
West Michigan Growers Group. 2020. Updates and opportunities for West Michigan farmers! https://mailchi.mp/d66fdb090b25/wmggfarmer-news-april-4th-2843374? $=\mathrm{d} 8 \mathrm{fded} 0 \mathrm{~d} 88$. Accessed 30 May

White, M. 2018. Freedom farmers: Agricultural resistance and the black freedom movement. Chapel Hill: The University of North Carolina Press.

White, S.K. 2019. What is process improvement? A business methodology for efficiency and productivity. Cio. https://www.cio.com/artic le/3433946/what-is-process-improvement-a-business-methodology-for-efficiency-and-productivity.html. Accessed 30 May 2020.

Wittman, H. 2011. Food sovereignty: A new rights framework for food and nature? Environment and Society: Advances in Research 2: $87-105$.

Publisher's Note Springer Nature remains neutral with regard to jurisdictional claims in published maps and institutional affiliations.

Sarah King was Associate Professor and Director of Environmental \& Sustainability Studies at Grand Valley State University during this project. Her research interests are in social innovation, environment, food and cultural/ecological systems.

Amy McFarland is Associate Professor of Environmental \& Sustainability Studies, and Acting Director of Environmental \& Sustainability Studies at Grand Valley State University. Her research interests are in horticulture and sustainable food systems.

Jody Vogelzang is Associate Professor (Allied Health Sciences) in the School of Interdisciplinary Health. She has research interests in community nutrition, health behavior and food insecurity, as well as in international sustainability. 